\title{
ASSESSMENT OF BUSINESS PROCESS MANAGEMENT FOR MSMES IN EAST JAVA
}

\author{
Umi Chotijah \\ Universitas Muhammadiyah Gresik \\ Jl. Sumatera No.101, GKB, Randuagung, Kec. Gresik, Kabupaten Gresik, Jawa Timur 61121 \\ E-mail: umi.chotijah@umg.ac.id
}

\begin{abstract}
The role of micro, small and medium enterprises (MSMEs) for the economies of many countries, especially Indonesia is very important. The garment industry is one of the industries of one of the processing sectors. The company needs understanding, documenting, modeling, analyzing, simulating, and implementing in order to increase value and achieve operational efficiency and survive business competition. Therefore it is necessary to know the level of management maturity of MSME business processes. The purpose of this study is to assess the level of maturity of business process management from MSMEs. First, the relevant literature is reviewed to gain insight into general business process management practices, the context of MSMEs in Indonesia and previous studies related to business process management in the context of MSMEs. The type of research used is qualitative. The research method in this research study is a case study. In this research study, the techniques used to obtain data were carried out through interviews and observations. Twelve samples in this study were garment MSMEs in East Java. The results of this study that the researcher can be concluded are six of MSMEs are included in the maturity level of adhoc BPM and six other MSMEs in definedpositions.
\end{abstract}

Keywords: Business process management, micro, small, medium enterprise, the garment industry

\begin{abstract}
Abstrak
Peran usaha mikro, kecil dan menengah (UMKM) bagi perekonomian banyak negara, terutama Indonesia sangat penting. Industri garmen adalah salah satu industri dari salah satu sektor pengolahan. Perusahaan memerlukan memahami, mendokumentasikan, memodelkan, menganalisis, mensimulasikan, mengimplementasikan, untuk meningkatkan nilai dan mencapai efisiensi operasional dan bertahan dari persaingan bisnis. Oleh karena itu perlu diketahui tingkat kematangan manajemen proses bisnis UMKM. Tujuan dari penelitian ini adalah untuk menilai tingkat kematangan manajemen proses bisnis dari UMKM. Pertama, literatur yang relevan ditinjau untuk mendapatkan wawasan tentang praktik manajemen proses bisnis secara umum, konteks UMKM di Indonesia dan studi sebelumnya terkait dengan manajemen proses bisnis dalam konteks UMKM. Jenis penelitian yang digunakan kualitatif. Metode penelitian dalam studi penelitian ini adalah studi kasus. Dalam studi penelitian ini, teknik yang digunakan untuk mendapatkan data dilakukan melalui wawancara dan observasi. Dua belas sampel pada penelitian ini yaitu UMKM garmen yang berada di Jawa Timur. Hasil dari penelitian ini diketahui enam UMKM di tingkat kematangan BPM ad-hoc dan enam UMKM yang lain di posisi defined.
\end{abstract}

Kata Kunci: Manajemen proses bisnis, usaha, mikro, kecil, menengah, industri garmen

\section{Introduction}

Competition in the current global economy is based on ability, or skills and accumulation of knowledge, which is carried out through organizational processes[1]. Every organization manages a large number of business processes. The business process determines what will be done, when and how, which enables companies to achieve their strategic goals[2]. The business process of an organization describes the ability of work carried out by all the resources involved in creating value results for customers and interested parties (suppliers, IT consultants, distributors, government policies, markets)[3].

$\mathrm{BPM}$ is a management discipline that focuses on improving organizational performance through improving, managing and controlling business processes[4]. In the past few years BPM has been much noticed because of its potential that significantly increase productivity and save costs, in managing business processes. BPM is process automation and process analysis for operations management and work organization [5].The characteristics of completeness of BPM have a negative side because it covers a variety of practices without many guidelines for how to implement them [6].

BPM must consider the different characteristics of the company. One of the main characteristics considered important context is the size of the company. Based on literature studies, 
most of the recent BPM empirical studies have been focused on large companies. An MSME has a type that is not the same as a large company[4].

There are several studies that focus on several aspects of BPM implementation in MSMEs. Previous research conducted by Chong (2006) explored the structure and main issues of BPM adoption and their implementation using empirical studies on 10 MSMEs in the wine industry in Australia. Imanipour et al. (2012) conducted a research with mixed methods to examine the main inhibiting factors in implementing business process management in MSMEs. They used 28 e-retail sector businesses in Iran. While Bhazenova et al. (2012) investigated the use of BPM and technology adoption in MSMEs in developing countries. Dallas and Wynn (2014) conducted BPM initiative research in a single case study of small businesses in Australia. These literatures provide a good basis on the potential for BPM implementation in MSMEs. However, studies mainly focus on one particular industry in a particular country, which means that the results may not applicable to other companies, types of industries and other countries. There is a need for similar studies from different industries and different countries. According to the Central Bureau of Statistics, it was stated that one of the developing processing industries in Indonesia in 2016 with an increase of $15 \%$ from 2015 was in the garment industry sector for micro and small businesses.

Some literatures state that the ability of MSMEs to compete in the global era depends on the internal aspects of MSMEs and external MSMEs [7]. Internal aspects of MSMEs include business scale, personality of business owners, educational background of business owners, and corporate culture can affect the amount of productivity and innovation of the company. The external aspects of MSMEs include market pressures, business competitors, access to capital and policies, both government policies and economic conditions of a country. Both aspects affect the development and growth of MSMEs [8].

In Indonesia, the potential of MSMEs as a driver of the economy, limited by resources, finance, less professional organizations, weak marketing, knowledge related to the utilization of business processes and ICT[9]. Our research previously attempted to measure the value of BPM in micro-enterprises in three sectors, namely food, furniture and garment in East Java[10].It was found that most MSMEs had a low maturity level of BPM so that it was still at the adhoc level.

This paper follows up our previous research, entitled the assessment of the maturity level of
BPM in MSMEs. So that it can be seen at what level of maturity twelve cases of MSMEs in the garment industry sector in the East Java region and whether internal factors and external factors of MSMEs are the drivers for the maturity of business processes for organizations.

\section{Literature}

\subsection{Business Process Management (BPM)}

The study of literature on business process management is widely publicized. There are several BPM classification topics, among others: 1) Ways of Thinking, which focus on the ontology of BPM as an important foundation that creates guiding principles; 2) How to work, which is a critical discipline that translates strategic planning and effective implementation. These topics include the BPM life cycle, business process Maturity Model, BPM role, process template, evidence-based BPM; 3) Modeling methods that discuss traditional modeling concepts to BPMN; 4) Ways of Implementation and Governance Methods address issues such as BPM change management, agile BPM, business process outsourcing, etc. [11].

One of the main areas of BPM that has received much attention is the development of maturity models related to business processes. Maturity levels allow organizations to understand their current process management and identify potential areas to increase their maturity. The business process orientation maturity model was first introduced by McCormack and Johnson (2001). In their model, they combine three basic components including process display, process work, process and management system measurement and two supporting components namely process structure and customer-focused process values and beliefs. Each component is further elaborated into several statements. Organizations are assessed based on their level of accuracy with statements (on five Likert scale points)

BPM practices can be grouped based on nine aspects, among others: 1) Strategic Views; 2) Process Definition; 3) Process Measurement; 4) Process Organizational Structure; 5) Management of employees; 6) Culture; 7) Market Orientation; 8) Supplier Relations; 9) Application of IS.

McCormack et al (2009) describes 4 (four) systematic stages of BPM maturity level, namely ad hoc, defined, linked, and integrated. Each step has attributes in it, and attributes at the next stage are based on the previous steps to create an increase in maturity level. The following 
definitions are given for the stage where an organization is business process oriented:

Ad-Hoc: The processes are unstructured and ill defined. Process measures are not in place and the jobs and organizational structures are based upon the traditional functions, not horizontal processes.

Defined: The basic processes are defined, documented and available in flow charts. Changes to these processes must now go through a formal procedure. Jobs and organizational structures include a process aspect, but remain basically functional. Representatives from functional areas (sales, manufacturing, etc.) meet regularly to coordinate with each other, but only as representatives of their traditional functions.

Perubahan proses harus melalui prosedur formal, pekerjaan dan organisasi ttruktur termasuk aspek proses, dan memiliki pertemuan rutin untuk berkoordinasi satu sama lain.

Linked:The breakthrough level. Managers employ process management with strategic intent and results. Broad process jobs, and structures are put in place outside of traditional functions.

Integrated:The company, its vendors and suppliers, take cooperation to the process level. Organizational structures and jobs are based on processes, and traditional functions begin to be equal or sometimes subordinate to process. Process measures and management systems are deeply imbedded in the organization.

Based on the four maturity levels according to McCormack and Johnson which can be seen in the following table:

TABLE 1

\begin{tabular}{cc}
\multicolumn{2}{c}{ TABLE 1 } \\
LEVEL OF BPMM \\
\hline Average & Level of BMPP \\
\hline $0-4$ & Ad hoc \\
$4-5,5$ & Defined \\
$5,55-6,5$ & Linked \\
$6,5-7$ & Integrated \\
\hline
\end{tabular}

\subsection{MSMEs in Indonesia}

Business is an economic unit that carries out activities with the aim of producing goods or services to be sold or exchanged for other goods and there is someone or more who is responsible and has the authority to manage the business [12]. According to Law Number 20 of 2008 concerning Micro, Small and Medium Enterprises, MSMEs are defined as productive businesses that are independent and carried out by individuals or small groups of people or business entities that are not subsidiaries or not branches owned, controlled or part of either directly or indirectly from a medium-sized business or large business with a certain amount of wealth and income in accordance with criteria determined by law and according to annual sales / turnover as shown in table 2 .

TABLE 2 DEFINITION OF MSME

\begin{tabular}{lcc}
\hline \multicolumn{1}{c}{ Constructs } & $\begin{array}{c}\text { Annual } \\
\text { Sales/Turnover } \\
\text { (Rupiah) }\end{array}$ & $\begin{array}{c}\text { Fixed/productive } \\
\text { assets (Rupiah) }\end{array}$ \\
\hline $\begin{array}{l}\text { Micro } \\
\text { enterprise }\end{array}$ & $<=300 \mathrm{~m}$ & $<=50 \mathrm{~m}$ \\
$\begin{array}{l}\text { Small } \\
\text { enterprise }\end{array}$ & $>300 \mathrm{~m}-<=2500 \mathrm{~m}$ & $>50 \mathrm{~m}-<=500 \mathrm{~m}$ \\
$\begin{array}{l}\text { Medium } \\
\text { enterprise }\end{array}$ & $>2500 \mathrm{~m}-<=50 \mathrm{bn}$ & $>500 \mathrm{~m}-<=10 \mathrm{bn}$ \\
\hline
\end{tabular}

\section{Methodology}

The first step in this study refers to the framework developed in our previous research [11], the next step is the development of research instruments based on research made by Skrinjar and Trkman (2013) regarding the measurement of BPM maturity of an organization [13]. Then the assessment rubric is made for BPM assessment criteria.

This research is a type of qualitative research. The research method used by researchers in this research study is a case study. In this research study, the techniques used to obtain data were carried out through interviews. In collecting data, researchers used a purposive sampling technique to determine who would be used as informants. To test the credibility of the data in this study, membercheck techniques were used. This study uses descriptive analysis techniques to analyze data by explaining or describing the data that has been collected. This descriptive analysis technique consists of three stages, namely: data reduction (data reduction), data display (data presentation), and conclusion drawing / verification (conclusion drawing). Respondents from this study were owners of garment / garment processing sector companies. Interviews and observations on each visit conducted by researchers to each informant with a duration of 2 hours to 3 hours. The researcher conducted 2 to 3 visits to each informant. The study was conducted from February 2018 to July 2018. The evaluation of the results of the interview was based on the level of accuracy of the answers to the informants with the assessment rubric that had been made using seven Likert scale points. 
4 Jurnal Sistem Informasi (Journal of Information System), Voume 15, Issue 1, April 2019

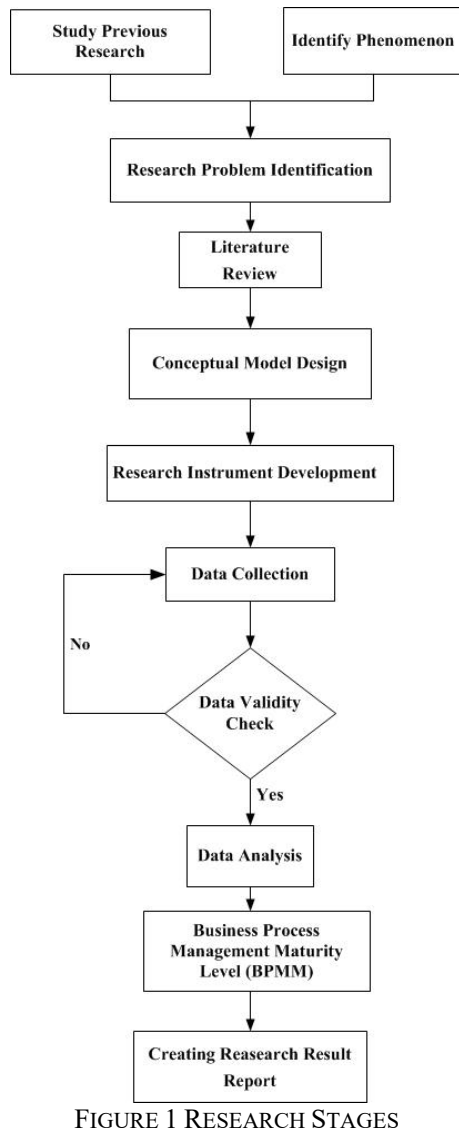

Table 3 below is a semi-structured question protocol used by researchers to interview business owners. The results of the interviews are then given a score of 1 to 7 based on the rubric that has been made.

TABLE 3

QUESTIONNAIRE OF SEMI-STRUCTURED

\begin{tabular}{|c|c|}
\hline Constructs & Questionnaire \\
\hline $\begin{array}{c}\mathrm{BPM} \\
\text { Implementation }\end{array}$ & \\
\hline Strategic View & $\begin{array}{l}\text { Is top management actively } \\
\text { involved in efforts to improve } \\
\text { processes and improve and redesign } \\
\text { business processes often on the } \\
\text { agenda at meetings with top } \\
\text { management? }\end{array}$ \\
\hline Process View & $\begin{array}{l}\text { Are the processes in the } \\
\text { organization documented with clear } \\
\text { input and output and have used } \\
\text { standard methodologies to describe } \\
\text { business processes? }\end{array}$ \\
\hline Process & Does the organizational structure \\
\hline $\begin{array}{l}\text { Organizational } \\
\text { Structure }\end{array}$ & $\begin{array}{l}\text { support the smooth implementation } \\
\text { of the process in the department? }\end{array}$ \\
\hline $\begin{array}{l}\text { Process Performance } \\
\text { Measurement }\end{array}$ & $\begin{array}{l}\text { Have process performance been } \\
\text { measured in the organization? }\end{array}$ \\
\hline $\begin{array}{l}\text { Culture, } \quad \text { Values, } \\
\text { Belief }\end{array}$ & $\begin{array}{l}\text { When members of several } \\
\text { departments gather, tension often } \\
\text { occurs? }\end{array}$ \\
\hline
\end{tabular}

\begin{tabular}{|c|c|}
\hline Constructs & Questionnaire \\
\hline People Management & $\begin{array}{l}\text { Are employees who have creative } \\
\text { talent enhanced and made a } \\
\text { breakthrough in improvement? }\end{array}$ \\
\hline Supplier Orientation & $\begin{array}{l}\text { Are changes to business processes } \\
\text { officially communicated to } \\
\text { suppliers? }\end{array}$ \\
\hline $\begin{array}{l}\text { Customer } \\
\text { Orientation }\end{array}$ & $\begin{array}{l}\text { Is customer satisfaction measured } \\
\text { systematically and often? }\end{array}$ \\
\hline \multicolumn{2}{|l|}{$\begin{array}{l}\text { Internal aspect of } \\
\text { MSMEs }\end{array}$} \\
\hline $\begin{array}{l}\text { Top Management } \\
\text { (Owner) }\end{array}$ & $\begin{array}{l}\text { Does the CEO have experience } \\
\text { related to the business being done } \\
\text { now? }\end{array}$ \\
\hline $\begin{array}{l}\text { Organizational } \\
\text { Characteristics }\end{array}$ & $\begin{array}{l}\text { Does your company have a clearly } \\
\text { defined organizational structure and } \\
\text { division of work tasks? }\end{array}$ \\
\hline \multicolumn{2}{|l|}{$\begin{array}{l}\text { External aspect of } \\
\text { MSMEs }\end{array}$} \\
\hline $\begin{array}{l}\text { Market, social, } \\
\text { business pressures }\end{array}$ & $\begin{array}{l}\text { Is there pressure from the market to } \\
\text { improve business processes? }\end{array}$ \\
\hline $\begin{array}{l}\text { Environmental } \\
\text { competitiveness }\end{array}$ & $\begin{array}{l}\text { Can improving business processes } \\
\text { survive in a competitive business } \\
\text { environment? }\end{array}$ \\
\hline New entrants & $\begin{array}{l}\text { Is it easy for newcompanies to enter } \\
\text { the market? }\end{array}$ \\
\hline
\end{tabular}

Respondents' profiles are displayed in Table 4.

TABLE 4

PROFILE OF INFORMANTS

\begin{tabular}{lcccl}
\hline Case & Gender & $\begin{array}{c}\text { Age } \\
\text { (yeras) }\end{array}$ & Education & $\begin{array}{c}\text { Business } \\
\text { Experience } \\
\text { (years) }\end{array}$ \\
\hline A & Female & 39 & Bachelor's degree & $>10$ \\
B & Male & 55 & Senior High School & $>10$ \\
C & Female & 61 & Bachelor's degree & $>10$ \\
D & Female & 48 & Primary School & $>10$ \\
E & Female & 30 & Senior High School & $6-10$ \\
F & Male & 43 & Bachelor's degree & $>10$ \\
G & Male & 62 & Senior High School & $>10$ \\
H & Male & 29 & Senior High School & $1-5$ \\
I & Female & 40 & Bachelor's degree & $>10$ \\
J & Male & 50 & Senior High School & $>10$ \\
K & Male & 62 & Junior High School & $>10$ \\
L & Female & 28 & Bachelor's degree & $>10$ \\
\hline
\end{tabular}

\section{Results and Analysis}

This section presents findings from case studies. First, a description of the case presented is followed by an analysis of the implementation of BPM, internal aspects of MSMEs and external aspects of MSMEs.

\subsection{Case Description}

First, the twelve cases were MSMEs based on the turnover obtained and the number of workers. Based on general information obtained from twelve MSME case studies, the following are Table 5 that show the characteristics of the general description of each MSME. For purposes of confidentiality, the company is presented in 
this paper as case $A$, case $B$, case $C$, case $D$, case $E$, case $F$, case $G$, case $H$, case $I$, case $J$, case $K$ and case $\mathrm{L}$.

TABLE 5

CASE DESCRIPTION

\begin{tabular}{|c|c|c|c|c|}
\hline Case & $\begin{array}{c}\text { Annual } \\
\text { Sales/Tur } \\
\text { nover } \\
\text { (Rupiah) }\end{array}$ & $\begin{array}{c}\text { Fixed/prod } \\
\text { uctive } \\
\text { assets } \\
\text { (Rupiah) }\end{array}$ & $\begin{array}{l}\text { Number of } \\
\text { employees }\end{array}$ & $\begin{array}{c}\text { Production } \\
\text { Method }\end{array}$ \\
\hline \multirow[t]{4}{*}{ A } & $>\operatorname{Rp} 2,5$ & $>\operatorname{Rp} 500$ & & Make-to- \\
\hline & Billion - & Million - & $>100$ & order\& \\
\hline & Rp 50 & Rp10 & People & Make-to- \\
\hline & Billion & Billion & & stock \\
\hline \multirow[t]{2}{*}{ B } & & $>\operatorname{Rp} 50$ & & \\
\hline & $\begin{array}{c}\text { Maximu } \\
\text { mRp } 300 \\
\text { Million }\end{array}$ & $\begin{array}{l}\text { Million - } \\
\text { Rp } 500 \\
\text { Million }\end{array}$ & 1 - 4 People & $\begin{array}{c}\text { Make-to- } \\
\text { order }\end{array}$ \\
\hline \multirow[t]{3}{*}{$\mathrm{C}$} & $>\operatorname{Rp} 2,5$ & $>\operatorname{Rp} 500$ & & Make-to- \\
\hline & Billion - & $\begin{array}{l}\text { Million - } \\
\text { Rp10 }\end{array}$ & $20-99$ & order\& \\
\hline & $\begin{array}{c}\text { Rp } 50 \\
\text { Billion }\end{array}$ & Billion & People & $\begin{array}{c}\text { Make-to- } \\
\text { stock }\end{array}$ \\
\hline \multirow[t]{3}{*}{$\mathrm{D}$} & $>\operatorname{Rp} 2.5$ & $>\operatorname{Rp} 500$ & & Make-to- \\
\hline & Billion - & $\begin{array}{c}\text { Million - } \\
\text { Rn10 }\end{array}$ & $20-99$ & order\& \\
\hline & $\begin{array}{c}\text { Rp } 50 \\
\text { Billion }\end{array}$ & Billion & People & Make-to- \\
\hline \multirow[t]{2}{*}{$\mathrm{E}$} & Maximu & Maximu & $5-19$ & Make-to- \\
\hline & $\begin{array}{c}\text { mRp } 300 \\
\text { Million }\end{array}$ & Million & People & $\begin{array}{l}\text { Make-to- } \\
\text { stock }\end{array}$ \\
\hline \multirow[t]{3}{*}{$\mathrm{F}$} & $>\operatorname{Rp} 300$ & $>\operatorname{Rp} 50$ & & \\
\hline & Million - & Million - & $5-19$ & order\& \\
\hline & $\begin{array}{l}\text { Kp 2,5 } \\
\text { Billion }\end{array}$ & Million & & $\begin{array}{c}\text { Make-to- } \\
\text { stock }\end{array}$ \\
\hline \multirow[t]{3}{*}{ G } & & $>\operatorname{Rp} 50$ & & \\
\hline & mRp 300 & Million - & $5-19$ & Make-to- \\
\hline & Million & Million & & order \\
\hline \multirow[t]{4}{*}{$\mathrm{H}$} & $>\operatorname{Rp} 300$ & $>\operatorname{Rp} 50$ & & \\
\hline & Million - & Million - & $5-19$ & Make-to- \\
\hline & $\begin{array}{l}\text { Rp 2,5 } \\
\text { Rillion }\end{array}$ & Rp 500 & People & order \\
\hline & Diाnणा & 1VHIIIU & & \\
\hline \multirow[t]{4}{*}{ I } & $>\operatorname{Rp} 300$ & $>\operatorname{Rp} 50$ & & \\
\hline & Million - & Million - & $5-19$ & \\
\hline & Rp 2,5 & Rp 500 & People & $\begin{array}{l}\text { Mrake-to- } \\
\text { order }\end{array}$ \\
\hline & Billion & Million & & \\
\hline \multirow[t]{4}{*}{$\mathrm{J}$} & $>\operatorname{Rp} 300$ & $>\operatorname{Rp} 500$ & & \\
\hline & Million - & Million - & $20-99$ & $\begin{array}{c}\text { Make-to- } \\
\text { order\& }\end{array}$ \\
\hline & Rp 2,5 & Rp10 & People & Make-to- \\
\hline & Billion & Billion & & stock \\
\hline \multirow[t]{3}{*}{ K } & $>\operatorname{Rp} 300$ & $>\operatorname{Rp} 500$ & & \\
\hline & Million - & Million - & $5-19$ & Make-to- \\
\hline & & & People & order \\
\hline \multirow[t]{2}{*}{$\mathrm{L}$} & $\geq \operatorname{Rp} 300$ & $\geq \operatorname{Rp} 5$ & 1 - 4 People & Make-to- \\
\hline & Million & Million & & stock \\
\hline
\end{tabular}

Assessments for the BPMM assessment process are based on the assessment criteria rubric in accordance with the development of previously made instruments. Scores for BPM with points 1 to 7.

\subsection{Analysis of BPMM in every Dimension}

In this section we will discuss the results of assessing the level of business process maturity in each dimension of BPMM assessment which is seen from the final average obtained in each dimension.

1) The dimensions of the strategic views of each case are shown in Table 6 below. In case A the average value is highest because the size of the medium business causes an increase and redesign of the business process and efforts to improve organizational processes and strategies are often discussed in meetings with top management. Whereas in other cases (micro-enterprises and small businesses) the agenda of such meetings is not there.

TABLE 6

DIMENSION OF STRATEGIC VIEW

\begin{tabular}{|c|c|c|c|c|c|c|c|}
\hline \multirow[b]{2}{*}{ ש্ } & \multicolumn{5}{|c|}{ Stategic View } & \multirow[b]{2}{*}{ 吾 } & \multirow[b]{2}{*}{ 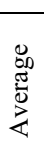 } \\
\hline & $\sum_{i s}$ & $\stackrel{N}{i s}_{0}$ & $\sum_{i s}^{m}$ & $\frac{\Delta}{\Delta}$ & $\stackrel{n}{n}_{i s}$ & & \\
\hline $\mathrm{A}$ & 6 & 6 & 6 & 7 & 6 & 31 & 6,2 \\
\hline B & 7 & 3 & 3 & 2 & 5 & 20 & 4,0 \\
\hline $\mathrm{C}$ & 6 & 7 & 6 & 6 & 3 & 28 & 5,6 \\
\hline $\mathrm{D}$ & 7 & 7 & 4 & 6 & 5 & 29 & 5,8 \\
\hline $\mathrm{E}$ & 7 & 1 & 1 & 6 & 3 & 18 & 3,6 \\
\hline $\mathrm{F}$ & 6 & 5 & 4 & 6 & 6 & 27 & 5,4 \\
\hline $\mathrm{G}$ & 7 & 1 & 2 & 3 & 3 & 16 & 3,2 \\
\hline $\mathrm{H}$ & 6 & 3 & 3 & 2 & 6 & 20 & 4,0 \\
\hline I & 5 & 5 & 4 & 6 & 6 & 2,6 & 5,2 \\
\hline $\mathrm{J}$ & 6 & 3 & 4 & 2 & 5 & 20 & 4,0 \\
\hline $\mathrm{K}$ & 6 & 3 & 2 & 5 & 5 & 21 & 4,2 \\
\hline $\mathrm{L}$ & 6 & 5 & 2 & 5 & 2 & 20 & 4,0 \\
\hline
\end{tabular}

2) The dimensions of the process view of each case are shown in table 7 below. There are 3 cases that have a high average rating on this dimension, namely cases A, C, and I. Case A is a medium business while case $\mathrm{C}$ and $\mathrm{I}$ are small businesses. The three cases have well defined the main business processes and supporting business processes in their organization, so that the whole process has been documented with clear input and output. Description of business processes (models) are available for each employee in each part of the work. Standard methodologies such as flowcharts have been used to describe their business processes. However, in 
nine other cases business processes, business process descriptions, and standard methodologies did not yet exist.

TABLE 7

\begin{tabular}{|c|c|c|c|c|c|c|c|c|}
\hline \multirow{2}{*}{$\begin{array}{l}\mathscr{J} \\
\tilde{J} \\
\tilde{J}\end{array}$} & \multicolumn{6}{|c|}{ Process View } & \multirow[b]{2}{*}{ 完 } & \multirow{2}{*}{ 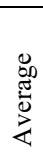 } \\
\hline & $\vec{z}$ & $\stackrel{2}{2}$ & $\stackrel{m}{z}$ & $\vec{z}^{+}$ & $\stackrel{n}{z}$ & $\gtrless^{\circ}$ & & \\
\hline $\mathrm{A}$ & 6 & 6 & 6 & 6 & 5 & 5 & 34 & 5,7 \\
\hline B & 3 & 3 & 3 & 3 & 2 & 3 & 17 & 2,8 \\
\hline $\mathrm{C}$ & 7 & 7 & 7 & 6 & 5 & 5 & 37 & 6,2 \\
\hline $\mathrm{D}$ & 5 & 5 & 5 & 5 & 4 & 3 & 27 & 4,5 \\
\hline E & 3 & 2 & 2 & 3 & 5 & 2 & 17 & 2,8 \\
\hline $\mathrm{F}$ & 5 & 5 & 5 & 5 & 4 & 3 & 27 & 4,5 \\
\hline G & 3 & 2 & 2 & 4 & 3 & 3 & 17 & 2,8 \\
\hline $\mathrm{H}$ & 6 & 2 & 3 & 6 & 3 & 2 & 22 & 3,7 \\
\hline I & 6 & 6 & 6 & 6 & 6 & 6 & 36 & 6,0 \\
\hline $\mathrm{J}$ & 3 & 2 & 4 & 3 & 2 & 2 & 16 & 2,7 \\
\hline $\mathrm{K}$ & 2 & 4 & 2 & 5 & 4 & 2 & 19 & 3,2 \\
\hline L & 5 & 2 & 5 & 5 & 2 & 2 & 21 & 3,5 \\
\hline
\end{tabular}

3) The dimensions of the organizational structure of the process of each case are shown in table 8 below. Case $\mathrm{C}$, has the highest average because there is already an organizational structure that can support the implementation of the process and responsibility for ownership of the process has been defined and made. In cases $\mathrm{A}, \mathrm{D}$, and $\mathrm{F}$ also have a fairly high average rating because the three cases have similarities, namely business processes that are also not simple, therefore the organizational structure has been formed as the responsibility of ownership in the implementation of processes in the organization. Whereas in other cases there is no formal organizational structure and only consists of two parts: owner and worker. The owner and his family handle most strategic and administrative tasks while workers handle production.

TABLE 8

DIMENSION OF PROCESS ORGANIZATIONAL STRUCTURE

\begin{tabular}{|c|c|c|c|c|c|c|c|c|c|}
\hline \multirow[b]{2}{*}{ 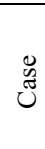 } & \multicolumn{7}{|c|}{ Process Organizational Structure } & \multirow[b]{2}{*}{$\stackrel{\bar{J}}{0}$} & \multirow[b]{2}{*}{ 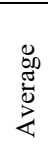 } \\
\hline & $\begin{array}{l}\overline{\tilde{n}} \\
\stackrel{0}{n}\end{array}$ & $\begin{array}{l}\text { Dे } \\
\infty \\
\infty\end{array}$ & $\begin{array}{l}\tilde{\hat{N}} \\
0 \\
\hat{2}\end{array}$ & 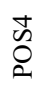 & $\begin{array}{l}\tilde{n} \\
0 \\
0\end{array}$ & $\begin{array}{l}\text { D } \\
\overbrace{0}\end{array}$ & $\begin{array}{l}\hat{n} \\
0 \\
0\end{array}$ & & \\
\hline A & 6 & 6 & 2 & 6 & 6 & 6 & 6 & 38 & 5,4 \\
\hline B & 6 & 3 & 4 & 5 & 3 & 3 & & 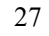 & 3,9 \\
\hline $\mathrm{C}$ & 5 & 7 & 5 & 7 & 5 & 7 & t & +3 & 6,1 \\
\hline D & 6 & 6 & 5 & 5 & 5 & 5 & & 37 & 5,3 \\
\hline E & 2 & , & 7 & 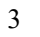 & 3 & 3 & & 24 & 3,4 \\
\hline $\mathrm{F}$ & 5 & 6 & 5 & 5 & 4 & 7 & 6 & 38 & 5,4 \\
\hline $\mathrm{G}$ & 5 & 1 & 4 & 3 & 6 & 5 & & 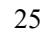 & 3,6 \\
\hline $\mathrm{H}$ & 3 & 0 & 2 & 2 & 2 & 5 & 3 & 23 & 3,3 \\
\hline I & 3 & 6 & 2 & 6 & 4 & 5 & 5 & 31 & 4,4 \\
\hline $\mathrm{J}$ & 3 & 6 & 2 & 2 & 2 & 5 & 2 & 22 & 3,1 \\
\hline K & 2 & 6 & 2 & 2 & 2 & 2 & 5 & 21 & 3,0 \\
\hline $\mathrm{L}$ & 2 & 5 & 2 & 4 & 2 & 3 & 3 & 21 & 3,0 \\
\hline
\end{tabular}

4) The dimensions of the process performance assessment of each case are shown in table 9 below. Case A, C, I, obtained a high average rating because the three cases besides defining and documenting the process steps for each existing process, making it easier to measure process performance. Whereas in other cases because the process and organizational structure are still simple, so business operations are very dependent on the owner. In addition, measurement and performance indicators are always measured but only limited to the production process.

TABLE 9

DIMENSION OF PROCESS PERFORMANCE MEASUREMENT

\begin{tabular}{|c|c|c|c|c|c|c|c|c|c|}
\hline \multirow{2}{*}{ 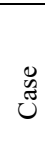 } & \multicolumn{7}{|c|}{$\begin{array}{c}\text { Process Performance } \\
\text { Measurement }\end{array}$} & \multirow[b]{2}{*}{ 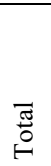 } & \multirow[b]{2}{*}{ 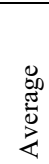 } \\
\hline & 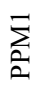 & 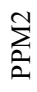 & 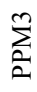 & 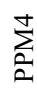 & 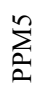 & 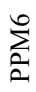 & 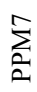 & & \\
\hline $\mathrm{A}$ & 6 & 6 & 6 & 6 & 6 & 6 & 6 & 42 & 6,0 \\
\hline B & 2 & 5 & 4 & 4 & 3 & 3 & 7 & 28 & 4,0 \\
\hline $\mathrm{C}$ & 5 & 7 & 5 & 5 & 6 & 6 & 7 & 41 & 5,9 \\
\hline $\mathrm{D}$ & 5 & 6 & 6 & 5 & 6 & 3 & 5 & 36 & 5,1 \\
\hline $\mathrm{E}$ & 3 & 6 & 7 & 7 & 7 & 2 & 6 & 38 & 5,4 \\
\hline $\mathrm{F}$ & 5 & 5 & 6 & 6 & 6 & 5 & 6 & 39 & 5,6 \\
\hline $\mathrm{G}$ & 2 & 4 & 2 & 2 & 2 & 2 & 2 & 16 & 2,3 \\
\hline $\mathrm{H}$ & 3 & 2 & 2 & 2 & 2 & 3 & 6 & 20 & 2,9 \\
\hline I & 6 & 6 & 6 & 5 & 6 & 5 & 6 & 40 & 5,7 \\
\hline $\mathrm{J}$ & 3 & 2 & 3 & 2 & 2 & 2 & 6 & 20 & 2,9 \\
\hline K & 2 & 2 & 6 & 2 & 2 & 2 & 6 & 22 & 3,1 \\
\hline $\mathrm{L}$ & 2 & 2 & 5 & 5 & 5 & 2 & 5 & 26 & 3,7 \\
\hline
\end{tabular}

5) The dimensions of culture, values, and beliefs of each case are shown in table 10 below. The highest average assessment for cases I and A. Organizational culture has been well developed, such as regular meetings between company owners and managers from various departments to discuss scheduled business process issues.

TABLE 10

DIMENSION OF CULTURE, VALUES AND BELIEFS

\begin{tabular}{|c|c|c|c|c|c|c|c|c|}
\hline \multirow[b]{2}{*}{$\underset{\mathbb{E}}{\mathbb{E}}$} & \multicolumn{6}{|c|}{ Culture, Values and Beliefs } & \multirow[b]{2}{*}{ స్ㅁㅇ } & \multirow[b]{2}{*}{ 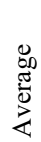 } \\
\hline & $\sum^{\bar{n}}$ & $\stackrel{N}{\infty}$ & $\stackrel{m}{p}$ & $\sum_{0}^{+}$ & $\sum^{n}$ & $\sum^{\infty}$ & & \\
\hline A & 5 & 6 & 4 & 5 & 7 & 3 & 30 & 5,0 \\
\hline B & 5 & 3 & 2 & 3 & 3 & 2 & 18 & 3,0 \\
\hline $\mathrm{C}$ & 3 & 5 & 2 & 5 & 7 & 7 & 29 & 4,8 \\
\hline D & 2 & 5 & 3 & 5 & 4 & 5 & 24 & 4,0 \\
\hline $\mathrm{E}$ & 3 & 7 & 4 & 6 & 4 & 3 & 27 & 4,5 \\
\hline $\mathrm{F}$ & 2 & 5 & 3 & 5 & 4 & 5 & 24 & 4,0 \\
\hline $\mathrm{G}$ & 1 & 3 & 2 & 1 & 1 & 1 & 9 & 1,5 \\
\hline $\mathrm{H}$ & 4 & 6 & 3 & 6 & 3 & 6 & 28 & 4,7 \\
\hline I & 5 & 6 & 6 & 6 & 6 & 3 & 32 & 5,3 \\
\hline $\mathrm{J}$ & 2 & 4 & 6 & 6 & 4 & 5 & 27 & 4,5 \\
\hline $\mathrm{K}$ & 2 & 6 & 2 & 6 & 2 & 6 & 24 & 4,0 \\
\hline $\mathrm{L}$ & 2 & 5 & 2 & 5 & 6 & 5 & 25 & 4,2 \\
\hline
\end{tabular}

6) The dimensions of employee management in each case are shown in table 11 below. In case 
$\mathrm{C}$ the highest average score is 5.8 (five point eight) because this company often provides training and debriefing to its employees both in terms of production processes and other business processes. Whereas in other cases, employees are not formally trained. However, training is provided by direct owners or fellow professional workers.

TABLE 11

DIMENSION OF PEOPLE MANAGEMENT

\begin{tabular}{|c|c|c|c|c|c|c|c|}
\hline \multirow{2}{*}{$\begin{array}{l}\tilde{J} \\
\tilde{J} \\
\tilde{J}\end{array}$} & \multicolumn{5}{|c|}{ People Management } & \multirow{2}{*}{$\stackrel{\pi}{0}$} & \multirow{2}{*}{ 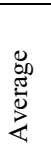 } \\
\hline & $\sum_{a}$ & $\sum_{\Sigma}^{O}$ & $\sum_{a}^{M}$ & $\sum_{a}^{+}$ & $\sum_{a}^{n}$ & & \\
\hline $\mathrm{A}$ & 5 & 5 & 4 & 6 & 3 & 23 & 4,6 \\
\hline B & 4 & 6 & 6 & 3 & 4 & 23 & 4,6 \\
\hline $\mathrm{C}$ & 7 & 5 & 7 & 7 & 3 & 29 & 5,8 \\
\hline $\mathrm{D}$ & 5 & 5 & 5 & 6 & 2 & 23 & 4,6 \\
\hline $\mathrm{E}$ & 4 & 3 & 4 & 7 & 4 & 22 & 4,4 \\
\hline $\mathrm{F}$ & 5 & 4 & 3 & 6 & 2 & 20 & 4,0 \\
\hline G & 3 & 1 & 1 & 6 & 5 & 16 & 3,2 \\
\hline $\mathrm{H}$ & 5 & 3 & 5 & 5 & 5 & 23 & 4,6 \\
\hline I & 5 & 5 & 5 & 6 & 2 & 23 & 4,6 \\
\hline $\mathrm{J}$ & 2 & 3 & 5 & 5 & 2 & 17 & 3,4 \\
\hline $\mathrm{K}$ & 2 & 2 & 2 & 5 & 4 & 16 & 3,2 \\
\hline $\mathrm{L}$ & 2 & 2 & 1 & 2 & 2 & 9 & 1,8 \\
\hline
\end{tabular}

7) The dimensions of supplier orientation in each case are shown in table 12 below. Cases that get the highest average rating are $\mathrm{A}, \mathrm{C}$, and $\mathrm{I}$. That is because they do partners (long-term relationships) with the main suppliers. Whereas in other case companies, they do not partner with major suppliers.

TABLE 12

\begin{tabular}{|c|c|c|c|c|c|}
\hline \multirow{2}{*}{$\underset{\tilde{\Xi}}{\tilde{\Xi}}$} & \multicolumn{3}{|c|}{ Supplier Orientation } & \multirow[b]{2}{*}{ 吾 } & \multirow{2}{*}{ 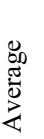 } \\
\hline & $\bar{o}$ & ชิ & ô & & \\
\hline $\mathrm{A}$ & 6 & 6 & 3 & 15 & 5,0 \\
\hline B & 1 & 5 & 1 & 7 & 2,3 \\
\hline $\mathrm{C}$ & 7 & 7 & 1 & 15 & 5,0 \\
\hline $\mathrm{D}$ & 3 & 6 & 2 & 11 & 3,7 \\
\hline $\mathrm{E}$ & 2 & 2 & 3 & 7 & 2,3 \\
\hline $\mathrm{F}$ & 3 & 3 & 1 & 7 & 2,3 \\
\hline G & 3 & 3 & 2 & 8 & 2,7 \\
\hline $\mathrm{H}$ & 6 & 3 & 2 & 11 & 3,7 \\
\hline I & 6 & 6 & 6 & 18 & 6,0 \\
\hline $\mathrm{J}$ & 5 & 3 & 2 & 10 & 3,3 \\
\hline $\mathrm{K}$ & 2 & 2 & 2 & 6 & 2,0 \\
\hline $\mathrm{L}$ & 1 & 2 & 2 & 5 & 1,7 \\
\hline
\end{tabular}

8) The dimensions of customer orientation in each case are shown in table 13 below. Case I and $\mathrm{J}$ get the highest average rating. Both cases design and develop products and services based on customer needs and expectations, because they conduct market studies first, besides that customer satisfaction measurements are measured systematically. Whereas in other cases because it is not supported by information technology or information systems so that measurement of customer satisfaction is not systematically measured, besides that market studies are also not conducted.

TABLE 13

DIMENSION OF CUSTOMER ORIENTATION

\begin{tabular}{|c|c|c|c|c|c|c|c|}
\hline \multirow{2}{*}{ ల్ } & \multicolumn{5}{|c|}{ Customer Orientation } & \multirow{2}{*}{ 胥 } & \multirow{2}{*}{ 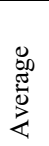 } \\
\hline & $\bar{o}$ & తి & ô & O্ & $\stackrel{2}{0}$ & & \\
\hline $\mathrm{A}$ & 5 & 6 & 4 & 1 & 5 & 21 & 4,2 \\
\hline B & 3 & 2 & 5 & 3 & 6 & 19 & 3,8 \\
\hline $\mathrm{C}$ & 5 & 7 & 2 & 1 & 5 & 20 & 4,0 \\
\hline $\mathrm{D}$ & 5 & 4 & 1 & 1 & 5 & 16 & 3,2 \\
\hline $\mathrm{E}$ & 3 & 4 & 1 & 1 & 1 & 10 & 2,0 \\
\hline $\mathrm{F}$ & 5 & 4 & 1 & 1 & 5 & 16 & 3,2 \\
\hline $\mathrm{G}$ & 4 & 1 & 4 & 5 & 4 & 18 & 3,6 \\
\hline $\mathrm{H}$ & 4 & 2 & 2 & 2 & 6 & 16 & 3,2 \\
\hline I & 5 & 5 & 5 & 6 & 2 & 23 & 4,6 \\
\hline $\mathrm{J}$ & 6 & 3 & 4 & 4 & 6 & 23 & 4,6 \\
\hline $\mathrm{K}$ & 2 & 2 & 2 & 6 & 4 & 16 & 3,2 \\
\hline $\mathrm{L}$ & 2 & 2 & 1 & 2 & 2 & 9 & 1,8 \\
\hline
\end{tabular}

Twelve cases with detailed mean values for each BPM dimension are shown in the graph below.

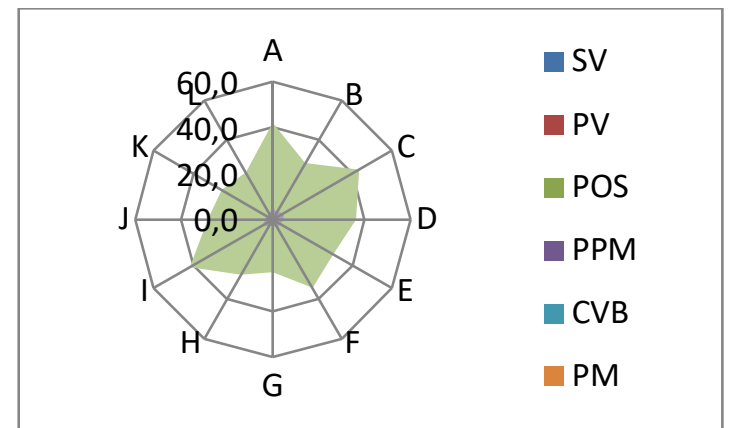

Figure 1. Dimension of BPM in Case

From the average of each dimension in the twelve cases, then it will be summed and calculated the average value to find out the BPMM level as in table 14 brought this.

TABLE 14

\begin{tabular}{ccc}
\multicolumn{4}{c}{ TABLE 14 } \\
\hline Case & Average & Level \\
\hline A & 5,3 & Defined \\
B & 3,6 & Adhoc \\
C & 5,4 & Defined \\
D & 4,5 & Defined \\
E & 3,8 & Adhoc \\
F & 4,3 & Defined \\
G & 2,9 & Adhoc \\
H & 3,5 & Adhoc \\
I & 5,2 & Defined \\
J & 3,6 & Adhoc \\
K & 3,2 & Adhoc \\
L & 3,0 & Adhoc \\
\hline
\end{tabular}




\section{Conclusions, implications and limitations}

The research findings support previous findings regarding the characteristics of small companies, the driving aspects and potential barriers to implementing BPM. The case companies involved in this preliminary study largely indicated the central role of owners in business, although there were a small number of companies that already had an organizational structure and functional assignment of tasks and were appointed to be responsible for the company's business processes. Garment companies, relatively simple businesses make owners limit business processes to order production and fulfillment. Overall, six case companies are at the adhoc level and the other six case companies are at defined levels. However, they have internal powers that can enlarge their business. On the external aspect, they also face pressure from their business competitors so they need to increase their competitive advantage. Case companies will benefit from BPM practices related to organizational structure, process modeling and documentation, performance measurement and more that involve managing culture and society.

This paper is limited in several aspects. The sample in this study was only twelve MSMEs and thus the results may be very dependent on this case. A survey to enable quantitative analysis of more questions related to the nature and extent of BPM implementation in MSMEs in East Java, Indonesia, factors that can drive the implementation of BPM in MSMEs in East Java, Indonesia and the BPM concept can benefit MSMEs. Furthermore, additional studies need to be conducted on MSMEs engaged in industries that have the same characteristics or different industries to obtain more optimal results.

\section{References}

[1] Kevin McCormack et al., "A global investigation of key turning points in business process maturity," Business Process Management Journal, vol. 15, no. 5, pp. 792815, September 2009.

[2] Van der Aalst, W. M.P., "Business process management: a comprehensive survey," Business Information System Engineering, pp. 1-37, 2012.

[3] Roger T. Burlton, "Delivering Business Strategy Through Process Management," in Handbook on Business Process Management 2 : International Handbooks on Information Systems, Second Edition, ed. Canada: Springer-Verlag Berlin Heidelberg, 2015, pp.
5-37.

[4] Ian Dallas and Moe Thandar Wynn, "Business Process Management in Small Business: A Case Study," springer, pp. 25-46, October 2014.

[5] Wil M. P. van der Aalst, Marcello La Rosa, and Flavia Maria Santoro, "Business Process Management Don't Forget to Improve the Process!," Business Information System Engineering, vol. 58, no. 1, pp. 1-6, 2016.

[6] Michael Rohloff, "Process Management Maturity Assessment," Americas Conference on Information Systems, 2009.

[7] Ovidiu Nicolescu, "Main Features of SMEs Organization System," Review of International Comperative, vol. 10, no. 3, 2009.

[8] BI, "Pemetaan dan Strategi Peningkatan Daya Saing UMKM dalam Menghadapi Masyarakat Ekonomi Asean (MEA) 2015 dan Pasca MEA 2025," Departemen Pengembangan UMKM Bank Indonesia (BI), 2016.

[9] http://presidenri.go.id/, "Potensi Besar UKM Industri Makanan-Minuman," 08/06/2016/ 12:02 WIB.

[10] Mahendrawathi Er, Nyoman P, and Umi C , "Business Process Management Practice for Micro Enterprise in Indonesia," in Proceedings of the 7th International Conference on Operations and Supply Chain Management (OSCM), Phuket, Thailand, December 2016, p. 115.

[11] Von Rosing M., Von Scheel H. , and Scheer, A.W., The Complete Business Process Handbook: Body of Knowledge from Process Modeling to BPM, Morgan Kaufmann.: Morgan Kaufmann, 2014.

[12] BPS, "Indeks Produksi Triwulanan Industri Mikro dan Kecil KBLI, 2011-2016," in https://www.bps.go.id/, 2015.

[13] Rok Škrinjar and Peter Trkman, "Increasing process orientation with business process management: Critical practices'," International Journal of Information Management, vol. 33, no. 1, pp. 48-60, Februari 2013.

[14] Umi Chotijah and Mahendrawathi ER, "Framework of Business Process Management (BPM) Assessment for MSMEs," 3rd International Seminar on Science and Technology (ISST): Green Science and Technology for Creative Research, vol. 3rd, no. 1007, p. 43, August 2017. 
[15] Umi Chotijah, "Penilaian Business Process Management (BPM) untuk Tingkat Kesiapan Implementasi Teknologi Informasi Pada UMKM di Jawa Timur: Multi Studi Kasus Pada UMKM Garmen, Pengolahan Makanan Dan Furnitur," Pascasarjana Sistem Informasi, ITS, Surabaya, 2017.

[16] Bank Indonesia, "Profil Bisnis UMKM," 2015.

[17] Trung Quoc Pham, "Measuring the ICT maturity of SME," researchgate, December 2015. 